\title{
The Boy Who Harnessed the Wind
}

\author{
By William Kamkwamba and Bryan Mealer \\ Published by HarperCollins Publishers 2010, 290 pages
}

Reviewed by:

Lizzie Dement (dementm@mailbox.sc.edu), Graduate Assistant for Social Justice and Diversity Education, University of South Carolina

Everyone faces challenges, however, The Boy Who Harnessed the Wind puts the average challenges faced by many Americans in perspective. The book is about William Kamkwamba who was born in Malawi, a third world country facing daily issues such as drought, hunger, and lack of education. Even though William faces these challenges daily, he is much different than many of the children in his community, in that he has ambition for change and discovery. Throughout the story, William's ambition for discovery and his town's survival are described as he learns to harness the wind.

The book begins with stories of magic that sound as if they could only be told centuries before, but quickly the reader learns that William was actually born in 1989 and all of these stories dictate the recent experiences of his community and his youth. William's family grows a few crops and lives season to season off of the proceeds from this work. His family's home is equipped with a few rooms, dirt floors, and with only a kerosene lamp for light; the world shuts down when the sun goes down. William attends a local school, but his family works hard to pay for his books every year, and his younger sisters are not guaranteed the opportunity to continue school.

William Kamkwamba and Bryan Mealer describe many of the challenges William faces throughout his journey of development in Malawi; however, one of the most powerful stories is the torture faced by William's community due to drought. With most of the community surviving on family crops, each family relies heavily on the annual rains to support their annual growth and harvest, "but in December 2000, everything went wrong" (pg. 76). With the rain beginning late, the crops were not supported, and farmers were not able to produce adequately to support their families. This turned into a catastrophe that affected the lives of the community for many consecutive years.

Throughout this experience, William also spends what little time he has left after tending to his family's crops focusing on his education. From an early age, it is noticeable that William has a passion for science, as he created a business fixing radios for locals in his community. Once he makes it into secondary school, William quickly realizes that his family cannot continue to pay for his fees. His father expresses shame as he struggles to pull together money to pay for his son's education, but when the family is only eating one meal a day and still struggling to pay his fees, William chooses to drop out of school.

Rather than giving up on his learning, William uses the resources of his town and pursues his own education by going to the local library weekly and sometimes daily to stay on top of his studies. Through the library, William begins to find textbooks and resources available about topics he never knew existed, including a book on energy and windmills. Through this discovery, William begins to dream of building a windmill for his town to provide light and a pump for water and irrigation to allow for harvests throughout the year. As he develops this plan, William has to make due with many of the materials he finds in his town such as metal found in scrap yards, wire that he barters for from neighbors, parts from bicycles, and more. With this extensive supply list and a system of trial and error, William works on this dream for over a year.

As community members begin to learn about William's project, many brush it off as child's play, but as William pursues his ambition for months and searches for more parts, rumors begin to 
spread. Some community members begin to question his mental state, but rather than leaving him to himself, they begin to blame his actions on black magic. With much of his town trying to stop him and even some of his family members questioning his choices, William feels lucky to have the support of his two friends Gilbert and Geoffrey as they help him pursue his dreams to make his community better.

The Boy Who Harnessed the Wind is written from a resilient viewpoint due to the cultural influences and extreme conditions that surround William Kamkwamba, making it very difficult for the reader not to be enticed into the story. This characteristic helps the reader feel connected to William and his experiences, making even his most random challenges of finding scraps for his windmill relatable to the life of the reader. The connection that is created from beginning to end establishes a number of areas for discussion and programming within new student programs.

One of the most powerful lines in this novel begins in William's childhood as he expresses the similarities between the children in his community and children across the world by saying:

I grew up in a small place in Africa, we did many of the same things children do all over the world, only with slightly different materials. And after talking with friends I've met from America and Europe, I now know this is true. Children everywhere have similar ways of entertaining themselves. If you look at it this way, the world isn't so big. (p. 19)

This perspective quickly makes the reader realize how little William regrets about his experiences or resents others for the privileges they have received throughout their lives. In addition to this, this creates a capacity within the reader to relate to William's experiences. This perspective has a great line for discussion to see how students relate, whether in extreme or similar situations to the experiences of William. One of the major experiences that could be used for discussion and programming for comparison include William overcoming the challenge of continuing his education due to financial constraints. Even though he is tasked with this, he makes the personal choice to push through this rather than give up, and continue to pursue his education on his own. Another relatable discussion topic is William's devotion to his family and community as he pushes to develop his windmill to bring electricity and water. Even when there is skepticism of his work in their eyes, he brings his project alive to his entire community because he believes in supporting those around him.

Throughout the story, readers learn of William's dog, Khamba, and through this, the topic of difficult choice comes alive. This part may be one of the most emotional sections of the book as William begins to realize during the famine that Khamba cannot survive and must make the choice to put his faithful companion down. Students may not all agree with this decision, but this can also bring up the discussion topic of decisions not always being agreed upon. Throughout all of these tough decisions and the journey of his personal discovery, there is also the discussion topic of the support of his friends and how students have experienced that throughout their development.

Finally, while discussing these relatable themes, there is the important topic of William's passion for discovery and invention that propelled him to create the windmill. This is a very relatable topic as passion may have brought many students to college, helped them choose their area of study, or even supported them in finding their involvements in life. This passion can also push students to continue to search for their passions so they have a driving force in their actions and daily life. With all of these areas of discussion, activities can be facilitated in many forms including personal essays of reflection, visual representations of experiences, or group discussions and presentations on similar journeys experienced with the "materials" of children in the United States.

Another wonderful area for development within new student programming can be though the book's focus on renewable energy and the nonprofit organization, TED, in which William becomes a Global Fellow throughout the course of the book. With renewable energy being a hot topic throughout higher education and America, it is really powerful to introduce the impact that one source of renewable energy can have on an entire community. 
The main concerns that come from utilizing this as a first-year or common reading come from students questioning or having difficulty dealing with choices that William makes in the book. One of the only major choices that may be difficult is William's personal choice to put his dog, Khamba, down as he begins to die of starvation. This section is not graphic, but William does describe the difficulty in the decision. Additionally, William does describe in detail some of his hunting, skinning of animals, and eating the skin of animals when he is starving. While this may not be a difficult subject for most students, it is important to note this area for concern when selecting this novel.

William Kamkwamba and Bryan Mealer provide a thought-provoking tale that reminds readers how much can be achieved through passion, commitment, and support. William's life is humbling, and it provides a relatable story that can allow new students an outlet for reflection on the life they have grown from and the life they plan to pursue. Due to the many obstacles William has overcome and the outlook he provides on life, The Boy Who Harnessed the Wind provides opportunities for discussion that any student can relate to and learn from, because when one really looks at it, we all have relatable experiences made out of "slightly different materials" (p. 19). 